or over, not one is considered to have components of the same colour. And of the forty-two pairs which are said to be of different colour all but two have more yellow in the brighter, so much so indeed that it is possible to suppose that the difference of brightness is the chief cause of the difference of colour. The two exceptions are :- -

$$
\begin{array}{lll}
\text { No. 23. } є \text { Bö̈lis } & \text { A. eq. Carulea } & \text { B. eq. Crrulea } \\
\text { No. 42. o } 507 & \text { A. Blanche } & \text { B. Cendriolivatre }
\end{array}
$$

There is evidently some error about No. 23. Either the colours are wrong, or it is wrongly stated to have differently coloured components. In No. 42 it is difficult to say which component is more yellow. Although, then, it is certain that other causes largely affect the colours of stars, yet differences of brightness seem to have the greatest effect in producing the apparent differences in the colours of double-stars.

Prof. Holden compares the colours of bright and faint stars to those of a more or less hot incandescent body. But in the latter case the dimmer light is accompanied with redness. We know that this is not the case with the light of our own sun; for of a white surface, upon part of which the sun shines, while the rest is in shadow, the darker part is bluer. In the same way, of the forty binaries of which the brighter component is the yellower, there are thirty-scven in which the fainter is bluer, and only three in which it is distinctly redder. It appears, therefore, that most double-stars do not differ greatly in colour from our sun, and do not shine with the strongly red light of an incandescent solid.

C. S. PeIrCE

Paris, July 20

\section{Coffee-Disease in New Granada}

THE following information about what appears to be a new disease of the coffee-tree is taken from an official letter written on April 29 last by Mr. C. Michelsen, Commissioner of Agriculture at Bogotá, to Mr. José Herrera, Vice-consul of New Granada in this city, who sent me a copy of it, requesting me to give him my opinion about the disease.

At first there appear on the leaves small spots of a lightgreenish colour, which in two or three days turn brownish, and then appears on each of them a fungus divided in three or more greenish-yellow branches. This fungus is said to be phosphorescent at night, and in places where it is very common a phosphoric smell is noted (!) After some days the diseased leaves fall off; the fruits, which also are attacked by the parasite, follow very soon, and the trees are left quite bare. They form, however, new leaves after some months, but these are again attacked by the fungus.

The disease is reported to be more frequent in damp places than in dry ones, its ravages being greatest in plantations where the trees are planted rather close. The fungus has alsoattacked the shade trees, especially the guamos (Inga sp.).

Though the description is far from being satisfactory, I think it is pretty clear that the fungus is not the Hemileia vastatrix of Ceylonese celebrity. However it bears a great resemblance to it, so that I recommended to employ fumigations with sulphur under the kind of large umbrella proposed by Mr. George Wall (NATURE, vol. xix. p. 423). The unusually rainy weather in the last year has very likely much to do with the spread of the disease, which at the same time is a new proof of the eminently fatal consequences resulting from close planting.

I have asked for dried specimens of diseased leaves, in order to submit them for examination to a competent mycologist.

Carácas, June 26

A. ERnst

\section{Toughened Glass}

ProbabLy the accident mentioned by $\mathrm{Mr}$. Noble Taylor is not exceptional, as a similar one happened to a member of my own family. She was about to take a seidlitz-powder, and had poured the contents of the blue paper into a tumbler of toughened glass half filled with cold water, and was stirring it gently to make the powder dissolve, when the tumbler flew into pieces with a sharp report. There was no fire or lamp in the room at the time. Some of the fragments flew to a distance of three or four feet. The bottom of the tumbler was not allogether fractured, but cracked into a number of little squares, which could be separated rcadily.

Edinburgh, July 20
THE same accident occurred to me a few nights ago as happened to your correspondent, and I cannot help thinking that the spoon had most to do with the phenomenon,

In a hot room I had just finished what is usually called a "lemon squash," i.e., the juice of a lemon and a little white sugar, with a bottle of soda-water, a lump of ice being put into the mixture. I was talking at the time, and so held the empty glass with a spoon in it in my hand for a second or two, when suddenly it went off in my hand into thousands of pieces, none larger than an inch or so.

I picked up one of the largest and thickest pieces, and found it to be so thoroughly disintegrated that I broke it up with my fingers into about a hundred small pieces, and might have done more. This disintegration seems to be a natural property of toughened glass when broken, but I never before saw a case of its breaking up without being struck. I do not think that usually such occurrences are dangerous, on account of the entire destruction of the fabric.

J. C. J.

\section{Large Hailstones}

ON Tuesday, July $\mathrm{I} 3$, at $2.30 \mathrm{p.m}$, hail began to fall heavily in this neighbourhood. A thunderstorm was at the time approaching rapidly from the north-east. I was struck with the extraordinary size of the stones, and going into the open air I collected six - the first that came to hand-in an accurately-tared glass, and weighed rapidly. 'The six stones weighed $5^{\circ} 766$ gram's. The average weight for each stone was therefore $96 \mathbf{r}$ gram. or I $4^{\circ} 8$ grains. A pane of glass in a skylight window had a hole driven through it by one hail-stone. GEORGE PATERson

Borax Works, Old Swan, Liverpool, Jnly I4

Chatel, Jersey.-Please send exact address.

\section{PAUL BROCA}

THE sudden death of the eminent French anthropologist, Dr. Paul Broca, which we announced a fortnight since, is an irreparable loss to science, and for the French medical and anthropological schools particularly.

Prof. Broca, born in 1824 at Ste. Foy la Grande(Gironde), was a senator, vice-president of the Academy of Medicine, officer of the Legion of Honour, and member of several learned societies. Since 1846 , the year in which he was promoted Aide d'anatomie, till 1880 , when he died as a professor of surgery, during nearly thirty-four years the life of Dr. Broca has been an uninterrupted consecration to science. A rapid review of his scientific work, especially of what he did for anthropology, will show how indefatigable was his zeal, how well his life has been spent.

Broca's publications on various subjects in anatomy, surgery, and anthropology are innumerable, especially his contributions to the last-mentioned subject. One has only to open the numerous volumes of the Bulletins of the Paris Anthropological Society, of the Mémoires and the Revue d'Anthropologie and other scientific journals, to get an idea of Broca's immense activity. In 1856 he published his famous "Traité des Anéurismes," which, with his "Traité des Tumeurs," published in 1866 , constitute his principal medical works. The former opened a new era in the treatment of these affections; in the latter Broca expounded the historical evolution of the knowledge of tumours and their treatment in so able a manncr that it has hitherto not been surpassed.

In $186 \mathrm{I}$ Broca made his remarkable discovery of the seat of articulate language at the third frontal convolution of the left side of the brain. Moreover in later years Broca devoted himself to the study of the brains of man and animals, greatly contributing to our knowledge on that subject. The Revue d'Anthropolorie contains many of the results of these studies; for instance, "Sur la Topographie cranio-cérébrale," "Etude sur le Cerveau du Gorille," "Anatomie comparée des Circonvolutions cérébrales," "Localisations cérébrales," \&c. 